\title{
Genetic Diversity of Trichoderma sp. from Rhizosphere Regions of Different Cropping Systems using RAPD Markers
}

\author{
A. Ranga Rani ${ }^{1 *}$, S. Khayum Ahammed ${ }^{2}$ and A.K. Patibanda ${ }^{3}$ \\ ${ }^{1}$ Department of Plant Pathology, S.V. Agricultural College, Tirupati, India \\ ${ }^{2}$ Scientist, Regional Agricultural Research Station, Nandyal, ANGRAU, India \\ ${ }^{3}$ Department of plant pathology, Agricultural College, Bapatla, India \\ *Corresponding author
}

\section{Keywords}

Trichoderma,

Genetic diversity,

RAPD,

Rhizosphere,

Different

cropping

systems.

Article Info

Accepted:

19 June 2017

Available Online:

10 July 2017

\section{A B S T R A C T}

A total of nine Trichoderma isolates were obtained from 27 rhizosphere samples collected from different cropping systems i.e. groundnut, redgram and tomato. A random amplified polymorphic DNA (RAPD) marker was used to estimate the genetic variation among 9 isolates of Trichoderma. These isolates were characterized using 15 random primers of the OPA and OPM series. Out of which 9 primers gave reproducible and scorable band with high percentage of polymorphism. Fifteen selected primers gave total of 207 amplification products, out of which 196 were polymorphic. The maximum polymorphism (100\%) was observed in PCR reaction with OPA-01, OPA-03, OPA-05, OPA-09, OPA-10, OPM-04 and OPM-20 with size ranging from $250 \mathrm{bp}$ to $2500 \mathrm{bp}$. The genetic distance between each isolate was calculated, and cluster analysis was used to generate a dendrogram showing the relationship among them. The Trichoderma isolates clustered into two major groups, first group having GRT-4, GRT-5, GRT-3 and TRT-1 in one cluster and remaining isolates GRT-1, GRT-2, RRT-2, TRT-2 and RRT-1 in other cluster which in turn grouped into two sub-clusters separating isolates GRT-1, GRT-2 formed one group and RRT-2, TRT-2 and RRT-1 formed another group. Similarity matrix thus produced indicated that maximum genetic variation observed between isolates of GRT-4 and RRT-2 (90.7\%) closely followed by GRT-3 with RRT-2 and TRT-2 (90.1\%). Isolates GRT-4 and GRT-5 were genetically closer than any isolate with $73.8 \%$ similarity. The isolate GRT-2 was closely related to isolate TRT-2 with $31 \%$ similarity and distinctly related to TRT-1 with $16.7 \%$ similarity.

\section{Introduction}

Trichoderma spp. are antagonistic to other fungi and have shown promise as biological control agents for several soil-borne diseases (Papavizas, 1985; Jenson and Wolffhechel, 1995). Several potentially useful strains of Trichoderma for the biological control are difficult to distinguish from other strains found in the field. So there is a need to find ways to monitor these strains when applied to the natural pathosystem. Some of the genera such as Trichoderma contain species that are of great economic importance because of their production of enzymes, abiotics or use as biocontrol agents (Harman, 2000). The molecular analysis of several strains revealed that the classification based on morphological data had been to a great extent, erroneous resulting in re-classification of several isolates 
and species (Meyer et al., 1993; Rehner and Samuels, 19995; Kuhls, et al., 1996). More recently, the use of molecular markers has given a boost to the analysis of the accurate variation among various isolates of these bioagents. Latha et al., (2002) reported that the RAPD (random amplified polymorphic DNA) techniques can be used for distinguishing strains of bioagents. By using the RAPD procedure (Williams et al., 1990), which incorporates the PCR (polymerase chain reaction) technique without depending on a known DNA sequence, information can be generated on amplification patterns from only a small amount of DNA. The present research work was undertaken to determine genetic variations among the isolates of Trichoderma spp. obtained from rhizosphere regions of ground nut, redgram, tomato fields using RAPD technique for evaluating their efficiency as biopesticides against major soil borne pathogens (Sclerotium rolfsii, Rhizoctonia solani, Macrophomina phaseolina, Fusarium oxysporum).

\section{Materials and Methods}

\section{Isolation of native antagonistic Trichoderma spp. from rhizosphere of groundnut, redgram and tomato}

A total of twenty seven rhizosphere soil samples were collected from rhizosphere of healthy plants in groundnut, redgram and tomato fields and shade dried. Serial dilution technique (Johnson and Curl, 1972) was used to isolate Trichoderma spp from rhizosphere of groundnut, redgram and tomato.

Antagonistic mycoflora were isolated on Trichoderma Selective Medium (TSM). The plates were incubated at $28 \pm 1^{0} \mathrm{C}$ and observed at frequent intervals for the development of colonies. Three days old colonies of Trichoderma were picked up and purified by single hyphal tip method.

\section{Fungal multiplication}

Potato dextrose broth (PDB) was used to get mycelial growth of fungus for extraction of DNA. One hundred and fifty $\mathrm{ml}$ of medium was dispensed in $500 \mathrm{ml}$ conical flasks and sterilized at $15 \mathrm{lb}$ p.s.i. for $20 \mathrm{~min}$. Each flask was inoculated with $6 \mathrm{~mm}$ mycelial disc of the fungus, taken from the actively growing single spore cultures of different isolates growing on Potato dextrose agar. The inoculated flasks were incubated for 10 days at $28 \pm 1^{\circ} \mathrm{C}$ in BOD incubator. At the end of incubation period, the mycelial mats were harvested by filtering through whatman paper no. 1 filter paper, washed with sterilized water thrice, blot dried and stored in Aluminiumfoils at $-20^{\circ} \mathrm{C}$.

\section{Nucleic acid extraction}

Total DNA was extracted by grinding fungal mycelia in a pre-sterilized pestle and mortar with liquid nitrogen until a fine powder was obtained and transferred to sterile Eppendorf tube. To this added $1 \mathrm{ml}$ of pre-heated $\left(65^{\circ} \mathrm{C}\right)$ extraction buffer (100 mM Tris (pH 8.0), 1.4 $\mathrm{M} \mathrm{NaCl}, 20 \mathrm{mM}$ EDTA, 2\% CTAB, 1\% PVP, $0.1 \%$ Mercaptoethanal) and incubated for 1 hour in water bath at $65^{\circ} \mathrm{C}$. Then tubes were centrifuged (Refrigerated Eppendorf centrifuge) at 10,000 rpm for $10 \mathrm{~min}$ at room temperature and the supernatant was collected into Eppendorf tubes. To this added equal volumes of phenol and chloroform (1:1). Then centrifuged the tubes at $10,000 \mathrm{rpm}$ for $10 \mathrm{~min}$ at room temperature and the supernatant was collected into Eppendorf tubes. To this added equal volumes of phenol and chloroform $(1: 1)$. Then centrifuged the tubes at $10,000 \mathrm{rpm}$ for $10 \mathrm{~min}$ at room temperature and the supernatant was collected into Eppendorf tubes. To this added equal volumes of chloroform and isoamyl alcohol (24:1) and $1 \mu \mathrm{l}$ RNase $(100 \mu \mathrm{g} / \mu \mathrm{l})$ and incubated at room temperature for 10-20 min. 
Then centrifuged the tubes at $10,000 \mathrm{rpm}$ for 10 min, separated the supernatant and added 0.1 volume of $3 \mathrm{M}$ sodium acetate $(\mathrm{pH} 4.8)$ and 0.6 volume (e.g. 300 $\mu 1$ then $0.6 \times 300=$ $180 \mu \mathrm{l})$ of ice cold isopropanol then incubated at $-20^{0} \mathrm{C}$ for overnight. After incubation, the tubes were taken out and centrifuged at $13,000 \mathrm{rpm}$ for $20 \mathrm{~min}$ at $4^{0} \mathrm{C}$. The supernatant was discarded and the pellet was washed with $70 \%$ alcohol and again centrifuged at $13,000 \mathrm{rpm}$ at $4{ }^{0} \mathrm{C}$ for $10 \mathrm{~min}$, discarded the supernatant, air dried the pellets and dissolved in $100 \mu \mathrm{l}$ of sterile distilled water. The DNA samples were stored at $20^{\circ} \mathrm{C}$ for further use.

\section{Purification of DNA}

RNase treatment was applied to remove RNA from the total nucleic acids. $2 \mu \mathrm{l}$ of RNase from a stock solution $(1 \mu \mathrm{g} / \mathrm{ml})$ were added to the nucleic acid extracts and incubated at $37^{\circ} \mathrm{C}$ for $1 \mathrm{~h}$. The DNA concentration of samples and their purity were determined by measuring ultraviolet absorbance at $260 \mathrm{~nm}$ and $280 \mathrm{~nm}$ in a spectrophotometer and rechecked by running samples along with 1 $\mathrm{kb}$ molecular weight marker (MBI, Fermentas) on $1 \%$ agarose gel.

\section{Standardization of polymerase chain reaction $(\mathbf{P C R})$}

The PCR was optimized by varying the content of template DNA $(25,50,75$ and 100 ng), Taq DNA polymerase (0.5- 3units) and $\mathrm{MgCl}_{2}$ concentration (5- $\left.25 \mathrm{mM}\right)$. The standardized amplification assay was as follows: template DNA, $100 \mathrm{ng}-2.0 \mu \mathrm{l}$, Taq DNA polymerase (Genei, Bangalore, India), $3 \mathrm{u} / \mu \mathrm{l}-0.4 \mu \mathrm{l}, \mathrm{MgCl}_{2}$, (25 mM) $2.0 \mu \mathrm{l}$, dNTPs (Genei), $100 \mathrm{Mm}-0.5 \mu \mathrm{l}$, primer (Operon Biotechnologies, Cologne, Germany), 25 p mol$4.0 \mu \mathrm{l}$, Taq buffer $(10 \mathrm{x}), 2.5 \mu \mathrm{l}$ in a reaction volume of $25 \mu \mathrm{l}$. Different PCR protocols given by Lee and Taylor (1990) and Pascual et al., (2000) were tested for obtaining the best amplification of nucleic acids of the isolates under investigation. The PCR was performed using a palmcycler (Carbett Research, Mortalake, Australia) with the following temperature profile: initial denaturation at $94^{\circ} \mathrm{C}$ for $5 \mathrm{~min}$, followed by 40 cycles of denaturation at $94^{\circ} \mathrm{C}$ for $1 \mathrm{~min}$, annealing at $37^{\circ} \mathrm{C}$ for $1 \mathrm{~min}$ and extension at $72^{\circ} \mathrm{C}$ for $2 \mathrm{~min}$, final extension: $72{ }^{\circ} \mathrm{C}$ for 5 minutes, Hold: at $4^{\circ} \mathrm{C}$.

\section{Primer survey and selection}

The preliminary primer screening was carried out using 15 primers from the OPA and OPM series (Operon Bio-technologies) for molecular variation analysis. The primers that gave reproducible and recordable amplification were used in the analysis of variability of the isolates.

\section{Agarose gel electrophoresis}

To $25 \mu \mathrm{l}$ of amplification products obtained after the PCR, $2 \mu \mathrm{l}$ of loading dye (bromophenol blue) were added and loaded into individual wells of $1.0 \%$ agarose in $1 \mathrm{x}$ TBE buffer. Electrophoresis was carried out at $100 \mathrm{~V}$ for $2 \mathrm{~h}$, and thereafter the gel was stained with ethidium bromide $\left(10 \mathrm{mg}^{-1} \mathrm{l}^{-1}\right)$. Detection of DNA was made on a transilluminator under UV light. The $1 \mathrm{~kb}$ ladder (MBI, Fermentas, Germany,) was also loaded in one lane as a marker. Each amplification product was considered as a RAPD marker and recorded across for all samples. Data were entered using a matrix in which all observed bands or characters were listed. The RAPD pattern of each isolate was evaluated assigning character state ' 1 ' to all bands that could be reproducibly detected in the gel and ' $\mathrm{O}$ ' for the absence of a band. The data matrix thus generated was used to calculate Jaccard's similarity co-efficient for each pairwise comparison. The co-efficients 
were calculated in silico, following Jaccard (1908), using the following formula: similarity coefficient $=a / n$, where $a$ is the number of matching bands for each pair of comparisons and $n$ is the total number of bands in two samples observed. The similarity co-efficients were subjected to the unweighted pair-group method on arithmetic averages (UPGMA) of cluster analysis to group the isolates based on their overall similarities. The SPSS 10.0 package was used for cluster analysis and subsequent dendogram preparation.

\section{Results and Discussion}

\section{Random amplification of polymorphic DNA}

The PCR conditions were optimized in terms of content of template DNA, Taq DNA polymerase and $\mathrm{MgCl}_{2}$ concentration. Varying contents of template DNA from 25 to $100 \mathrm{ng}$ in a reaction volume of $25 \mu \mathrm{l}$ and 100 ng DNA gave the maximum number of reproducible bands, and thus was considered ideal and used subsequently in all analysis. Titration of different contents of Taq DNA polymerase and $\mathrm{MgCl}_{2}$ showed that 3 units of Taq DNA polymerase and $25 \mathrm{mM} \mathrm{MgCl}_{2}$ in the final reaction mixture gave optimum, reproducible and well resolved results. A higher or lower content resulted in either suboptimal or lack of complete amplifications. The final amplification assay contained 100 ng genomic DNA, 3 units Taq DNA polymerase, $100 \mathrm{mM}$ each of dNTPs, $25 \mathrm{mM}$ $\mathrm{MgCl}_{2}, 25$ picomoles of $4.0 \mu \mathrm{l}$ primer and 10x Taq buffer in a PCR reaction volume of $25 \mu \mathrm{l}$.

\section{Primer selection and survey}

Primer survey was carried out by using 15 primers from OPA and OPM series of (Operon technology Inc.USA). Out of 15 primers used for amplification of DNA for all isolates of Trichoderma viride, 9 primers were gave reproducible and scorable band with high percentage of polymorphism. Hence the final numerical analysis included results from 9 primers amplification. PCR amplification with 15 primers was done twice before scoring for presence and absence of bands. Number of amplification products obtained was specific to each primer and it was ranged from 5 to 26. Fifteen selected primers gave total of 207 amplification products, out of which 196 were polymorphic (Table 1).

The maximum polymorphism was observed in PCR reaction with OPA-01, OPA-03, OPA-05, OPA-09, OPA-10, OPM-04 and OPM-20. These primers showed $100 \%$ polymorphism as all the bands obtained were polymorphic with size ranging from $250 \mathrm{bp}$ to 2500 bp. RAPD pattern was established for the nine isolates of Trichoderma spp. The banding pattern was found to be distinct as exhibited by primers OPA-03, OPA-09, OPA10 and OPM-04. Jaccard similarity coefficient between the isolates were calculated (Table 2). Similarity matrix thus produced indicated that maximum genetic variation observed between isolates of GRT-4 and RRT-2 (90.7\%) closely followed by GRT-3 with RRT-2 and TRT-2 (90.1\%). Isolates GRT-4 and GRT-5 were genetically closer than any isolate with $73.8 \%$ similarity. The genetic variation between the isolates GRT-1 with rest of other isolates oscillated in between 55.1 to $78.6 \%$. The closest isolate was GRT-2 with $44.9 \%$ similarity, which showed maximum variation with the isolate RRT-2 (78.6\%). The isolate GRT-2 was closely related to isolate TRT-2 with $31 \%$ similarity and distinctly related to TRT-1 with $16.7 \%$ similarity. Isolate GRT-3 closely related to two isolates with similarity more than $36 \%$, closest one is being isolate GRT-4 and GRT-5 with 36.5 and $36.1 \%$ similarity 
respectively. Maximum genetic distance from isolate RRT-2 and TRT-2 is with $90.1 \%$ dissimilarity. Isolate GRT-4 and GRT-5 was found to be identical with $73.8 \%$ similarity followed by RRT-2 and TRT-2 with $50 \%$ similarity. These similarity co-efficients were subjected to Unweighted Pair Group Method on Arithmetic average (UPGMA) and a dendrogram was drawn using SPSS package (Fig. 1).

Table.1 Primer survey for determination of polymorphism in Trichoderma isolates

\begin{tabular}{|c|c|c|c|c|}
\hline S. No. & $\begin{array}{c}\text { Operon } \\
10 \text { mer set } \\
\text { A\&M }\end{array}$ & Sequence & $\begin{array}{c}\text { Total number of } \\
\text { bands }\end{array}$ & Polmorphic bands \\
\hline 1 & OPA-01 & $5^{1}(\mathrm{CAG}$ GCC TTC $) 3^{1}$ & 19 & 17 \\
\hline 2 & OPA-03 & $5^{1}$ (AGT CAG CCA C) $3^{1}$ & 26 & 23 \\
\hline 3 & OPA-04 & $5^{1}\left(\mathrm{AAT}\right.$ CGG GCT G) $3^{1}$ & 5 & 5 \\
\hline 4 & OPA-05 & $5^{1}\left(\mathrm{AGG}\right.$ GGT CTT G) $3^{1}$ & 23 & 22 \\
\hline 5 & OPA-08 & $5^{1}\left(\right.$ GTG ACG TAG G) $3^{1}$ & 9 & 9 \\
\hline 6 & OPA-09 & $5^{1}\left(\right.$ GGG TAA CGC C) $3^{1}$ & 25 & 23 \\
\hline 7 & OPA-10 & $5^{1}\left(\right.$ GTG ATC GCA G) $3^{1}$ & 24 & 23 \\
\hline 8 & OPA-11 & $5^{1}(\mathrm{AGA} C G G \mathrm{CTC} C) 3^{1}$ & 7 & 7 \\
\hline 9 & OPM-02 & $5^{1}\left(\right.$ GTT GGT GGC T) $3^{1}$ & 8 & 8 \\
\hline 10 & OPM-04 & $5^{1}\left({\text { GGC GGT TGT C) } 3^{1}}^{1}\right.$ & 20 & 19 \\
\hline 11 & OPM-06 & $5^{1}\left(\mathrm{CTG}\right.$ GGC AAC T) $3^{1}$ & 7 & 7 \\
\hline 12 & OPM-10 & $5^{1}\left(\right.$ TCT GGC GCA C) $3^{1}$ & 9 & 9 \\
\hline 13 & OPM-16 & $5^{1}\left(\right.$ GTA ACC AGC C) $3^{1}$ & 8 & 8 \\
\hline 14 & OPM-18 & $5^{1}(\mathrm{CAC}$ CAT CCG T $) 3^{1}$ & 6 & 6 \\
\hline 15 & OPM-20 & $5^{1}\left(\right.$ AGG TCT TGG G) $3^{1}$ & 11 & 10 \\
\hline
\end{tabular}

Total number of band $=207$

Polymorphic bands $=196$

Per cent of polymorphism $=94.6$

Table.2 Jaccard's similarity co-efficient of nine isolates of Trichoderma based on polymorphism obtained with fifteen random primers

\begin{tabular}{|c|c|c|c|c|c|c|c|c|c|}
\hline \multicolumn{7}{|c|}{ Proximity Matrix } \\
\hline & \multicolumn{3}{|c|}{} \\
\cline { 2 - 12 } & GRT1 & GRT2 & GRT3 & GRT4 & GRT5 & RRT1 & RRT2 & TRT1 & TRT2 \\
\hline GRT1 & 1 & & & & & & & & \\
\hline GRT2 & 0.449 & 1 & & & & & & & \\
\hline GRT3 & 0.298 & 0.275 & 1 & & & & & & \\
\hline GRT4 & 0.292 & 0.237 & 0.361 & 1 & & & & & \\
\hline GRT5 & 0.304 & 0.257 & 0.365 & 0.738 & 1 & & & & \\
\hline RRT1 & 0.268 & 0.306 & 0.126 & 0.139 & 0.188 & 1 & & & \\
\hline RRT2 & 0.214 & 0.267 & 0.099 & 0.093 & 0.124 & 0.262 & 1 & & \\
\hline TRT1 & 0.235 & 0.167 & 0.223 & 0.231 & 0.278 & 0.283 & 0.125 & 1 & \\
\hline TRT2 & 0.269 & 0.310 & 0.099 & 0.124 & 0.147 & 0.359 & 0.500 & 0.212 & 1 \\
\hline
\end{tabular}


Fig.1 Dendrogram depicting variation among isolates of Trichoderma spp. based on RAPD analysis

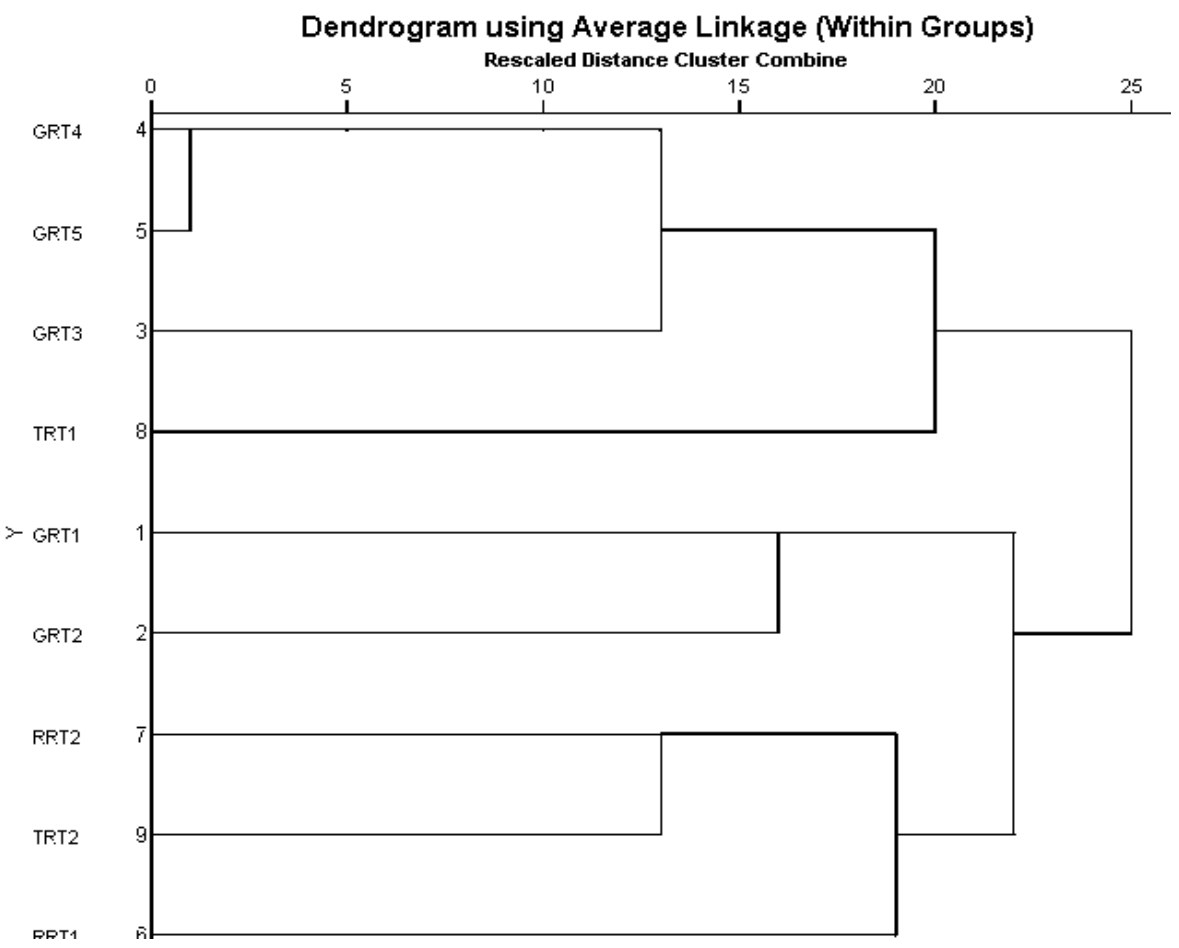

The prominent outcome of this analysis is that the Trichoderma isolates clustered into two major groups, first group having GRT-4, GRT-5, GRT-3 and TRT-1 in one cluster and remaining isolates GRT-1, GRT-2, RRT-2, TRT-2 and RRT-1 in other cluster which in turn grouped into two sub-clusters separating isolates GRT-1, GRT-2 formed one group and RRT-2, TRT-2 and RRT-1 formed another group.

Molecular characterizations of different Trichoderma isolates are not available and there were no specific markers to differentiate the isolates effectively. The RAPD technique revealed some degree of polymorphisms for variation study of thirty five Trichoderma isolates in the present study and the results obtained from the experiment showed significant molecular variation among the isolates in relation to morphological characters. Therefore, findings of the present investigation agree with the report of
Chakraborty et al., (2010) who found the variability based on RAPD analysis among nineteen isolates of $T$. viride and $T$. harzianum obtained from rhizosphere soil of plantation crops, forest soil, and agricultural fields of North Bengal. Gopal et al., (2008) investigated RAPD markers to estimate the genetic variation among 17 isolates of Trichoderma, and found them genetically similar showing $91.8 \%$ polymorophism, which corroborates with the observation of our investigation. Gurumurthy et al., (2013) studied genetic variation of Trichoderma isolates using a set of 20 RAPD primers. They concluded that out of total 20 decamers of operon $\mathrm{H}$ primer series 12 primers namely $\mathrm{OPH}$ - 1, OPH - 3, OPH - 4, OPH - 5, OPH 7, OPH - 9, OPH - 11, OPH - 13, OPH - 14, OPH - 16, OPH - 18 and OPH - 19 showed the amplification which was a good sign to predict the genetic diversity and molecular variability in the Trichoderma spp. isolated from chickpea fields of Uttar Pradesh. 
Mukesh et al., (2014) studied molecular variability among eight isolates of Trichoderma atroviride, they showed 74 amplified bands out of which 65 were polymorphic and 19 were monomorphic. The size of amplified product varied from $0.1 \mathrm{~kb}$ to $0.75 \mathrm{~kb}$. On the other hand, Chandulal et al., (2016) analyzed the genetic diversity among ten isolates of Trichoderma sp. obtained from the rhizosphere soil of tomato fields with five random RAPD primers. The percentage of polymorphism ranged from $60.00 \%$ to $83.33 \%$ and revealed intra and inter-specific variability amongst Trichoderma isolates examined. The present study can be concluded that the purification, cloning and sequencing of selected amplificans which are being performed will allow the development of Trichoderma specific primers to be used in a fast and reliable screening of effective isolates by PCR.

\section{References}

Chakraborty, B.N., Chakraborty, U., Saha, A., Dey, P.L., and Sunar, K. 2010. Molecular characterization of Trichoderma viride and T. harzianum isolated from soil from North Bengal based on rDNA markers and analysis of their PCR-RAPD profiles. Global J. Biotechnol. Biochem., 5(1): 5561.

Chandulal, K., Priya John., and Chopada Gopal. 2016. Genetic diversity of Trichoderma sp. obtained from tomato rhizosphere using rapd. Int. J. Sci. Environ. Technol., 5(4): $2101-2108$.

Gopal, K., Sreenivasulu, Y., Gopia, V., Prasadbabua, G., Kumar, T.B.,
Madhusudhana, P., Ahemeda, S.K., and Palanivel, S.G. 2008. Genetic variability and relationships among seventeen Trichoderma isolates to control dry root rot disease using RAPD markers. J. Biosci., 63: 740-746.

Gurumurthy, S., Senjam Jinus, S., Karthik Reddy, $\mathrm{P}$ and Anjan Kumar, S. 2013. RAPD analysis of Trichoderma spp. isolated from chickpea fields of Uttar Pradesh. Int. J. Adv. Res., 1(8): 335-340.

Harman, G.E. 2000. The myths and dogmas of biocontrol: Changes in perceptions derived from research on Trichoderma harzianum strain T-22. Plant Dis., 84: 377-393.

Kuhls, K.E., Lieckfeldt, G.J., Kovacs, S.W., Meyer, W., Petrini, O., Gams, W., Borner,T., and Kubicek, C.P. 1996. Molecular evidence that the asexual industrial fungus Trichoderma reesei is a clonal derivative of the ascomycete Hypocrea Jecorina. Proc. Natn. Acad. Sci. USA, 93: 7755-7760.

Meyer, W.E., Lieckfeldt, G.J., Kuhls, K.E., Freedman, E.Z., Borner, T., and Mitchell,T.J. 1993. DNA and PCR Fingerprinting in fungi. In: DNA fingerprinting. S.D.J. Pena; R. Chakraborty; J.T. Epplen and A.J. Jeffreys (eds.). State of the Science. Birkhauser Verlag, Basel, Switzerland. PP: 311-320.

Mukhesh, S., Singh, A., and Srivastava, D.K. 2014. Morphological and molecular characterization of Trichoderma isolates: An antagonist against soil borne pathogens. Int. J. Sci. Res., 3(7): 2399-2404.

Rehner, S.A., and Samuels, G.J. 1995. Molecular systematics of the Hypocreales: A teleomorph gene phylogeny and the status of their anamorphs. Can. J. Bot., 73: 58165823 .

\section{How to cite this article:}

Ranga Rani, A., S. Khayum Ahammed, Patibanda, A.K. 2017. Genetic Diversity of Trichoderma Sp. from Rhizosphere Regions of Different Cropping Systems using RAPD Markers. Int.J.Curr.Microbiol.App.Sci. 6(7): 1618-1624.

doi: https://doi.org/10.20546/ijcmas.2017.607.195 